\title{
Quality of Accounting Graduates: A Survey of Employers in Nigeria
}

\author{
Samiat Oluwatoyin AFOLABI. \\ Federal College of Education (Technical) Asaba, Delta State 2012/2013
}

\begin{abstract}
This study examined the quality of accounting graduates based on a survey of employers in Nigeria. The study was prompted by a perceived gap between the skills possessed by accounting graduates and the skills needed by employers. Specifically, the study investigated the private and public sectors perception of the quality of accounting graduates for skills required by employers, whether educational institutions provided the skills most vital to the graduates and as needed by employers and employers' perception of the differences among the accounting graduates. The study adopted a survey research design method. The population of the study consisted of all private and public business enterprises in the area. Sample for the study consisted of 350 respondents made up of 225 and 125 private and public business enterprises, respectively. Data were collected through the use of copies of well structured questionnaire. Descriptive statistics of frequency, rated mean and mean rankings were used in analyzing the data. The hypotheses were tested using student $t$-distribution statistics with the aid of a MINTAB Student computer software. The findings of the study showed that today's accounting graduates were computer literate and possessed insufficiency of skills in accounting procedures and principles, as well as initiatives. More so the study found out that there were significant differences between the private and public employers' perception of the quality of accounting graduates, in the quality of accounting graduates as needed by the private and public employers and in the skills most vital to accounting graduates as perceived by the private and public employers. Based on the findings of this study, it was recommended that the National Universities commission and other agencies should work in synergy with the business world to get the latest input on business developments and requirements, which can be achieved by organizing trainings and workshops.
\end{abstract}

\section{Introduction}

Education is a basic objective of development and an important end in itself. It is essential for a satisfying and rewarding life. Education is fundamental to the broader notion of expanded human capabilities that lie at the heart of the real meaning of development. In other words, any development efforts that lack education foundation is faulty. Todaro and Smith (2009) observed that education plays a key role in the ability of a developing country to absorb modern technology and to develop the capacity for self-sustaining growth and development. Oxford advanced learners dictionary defines education as "a process of teaching, training and learning, especially in schools or colleges, to improve knowledge and develop skills." Accounting education can therefore be defined as the process of teaching, training and learning to improve knowledge and develop skills in accounting.

The importance of having a sustained programme for improving audit and Accounting Education in Nigeria cannot be over emphasized. Porwal (2006) noted that "accounting has developed over the years from the art of recording, classifying and summarizing of economic events, to become a service activity, a descriptive and analytical discipline and an information system". Accounting today is the language of business, and business has gone global, breaking the barriers of national boundaries. Therefore, if accounting must continue to be the language of business, it has to move at the same pace with business and accounting graduates. The needs of users of financial information are varied and dynamic. International business and investments are based on the credibility, reliability, truth and fairness of financial information provided to local and cross border investors. The auditing and accounting profession is relied upon to input these qualities to the financial information either as employees of the business organizations or as external auditors. Except the accountants are well educated, trained and imbued with the desire to learn, they may not be able to cope with the challenges of the modern and dynamic business world. Concerned about the quality of accounting graduates and other disciplines is on the rise in Nigeria. It comes at a time of growing recognition of the potentially powerful role of tertiary education for growth, and it is a natural response to public or employers perception that educational quality is being compromised in the effort to expand enrollment in recent years. It is also timely because of the growing complaints by employers that graduates are poorly prepared for the workplace and increasing competition in the higher education for market places as numerous private and transnational providers enter the scene. Thus, the study intends to find out the quality of accounting to see if their graduates meet the skills requirements needed by the employers in Nigeria. 


\section{Statement of the Research Problem}

Education in a broad sense is a process by which an individual acquires the many physical and social capabilities demanded by the society in which he/she is born into function. Education is an ultimate value and hence, through the provision of social services, it is an agent of change. The essence of education, whether formal or informal, is to produce persons who will be a useful member of a society. According to Dogle sited in Orobosa (2010), education must engender in the individual a disposition of personal autonomy, responsibility and relevant forms of life thought and action. Private and public sectors are becoming conscious of the need for effective quality of accounting graduates. The sectors express concern about the need to improve quality of accounting graduates and other disciplines, the need to reassure the public about the quality of private providers, and the importance of ensuring that higher educational institutions offer and meets acceptable local and international standards. Changes brought by the transition to a knowledge economy have created a demand for higher skill levels in most occupations. A new range of competence such as adaptability, teamwork, communication skills and the motivation for continual learning have become critical. The importance of skills on employability of accounting graduates in Nigeria labour market by employers of labour, reveal that some skills are lacking. Williams (2003) cited in Adamu and Dandago (2013) reported that graduates are deficient in transferable skills, teamwork initiation and others, required of the work form in the modern era. According to Singh and Singh (2008), employers have urged institutions (universities) to make more explicit efforts towards developing "key" "core", "transferable", "soft", "employable" and/or a generic skills needed in many types of employment. The above prompted the researcher to investigate the quality of accounting graduates in Nigeria and the perception of both public and private companies in Nigeria to see whether accounting graduates meet the skills required by these employers.

\section{Research Questions}

1. What is the public and private sectors perception of the quality of accounting graduates for skill requirements as produced by educational institutions?

2. What are the skills most vital to accounting graduates as needed by employers?

3. What are employers' perceptions of the differences in skills acquisition among the accounting graduates?

\section{Objectives of the Study}

The broad objective of the study was to examine the quality of accounting graduates as perceived by employers in Nigeria. The study specifically:

1. Investigated the public and private sectors perception of the quality of accounting graduates for skill requirements as produced by educational institutions.

2. Investigated the skills most vital to accounting graduates as needed by employers.

3. Examined employers' perceptions of the differences in skills acquisition among the accounting graduates.

\section{Research hypotheses}

$\mathbf{H}_{\mathbf{0 1}}$ : There is no significant difference between private and public employers' perceptions of the quality of accounting graduates.

$\mathbf{H}_{\mathbf{0} 2}$ : There is no significant difference between the quality of accounting graduates needed by the private and public employers in Nigeria.

$\mathbf{H}_{\mathbf{0} 3}$ : There is no significant difference between the skills that are most vital to accounting graduates as perceived by the private and public employers.

\section{Significance of the study}

The findings of this study may be useful to the Ministry of Education, the government, Institute of Chartered Accountants of Nigeria (ICAN), Association of National Accountants of Nigeria (ANAN), institutions of higher learning and the business environment. The findings of the study is hoped to give open eyes to the higher education institutions of quality of accounting graduates in meeting the needs of their customers. It may also provide a guideline to the government, policy makers, and the curriculum planners now and in the future. The recommendations of this study if applied by business and institutions would help them in creating higher standards of quality in accounting.

\section{Review of Empirical Literature}

Quality of education is becoming more important as the government is moving towards knowledge economy in which human resources play an ever-increasing key role in a world competitive environment. This is certainly apparent in higher education where the products of the system, i.e graduates can have a direct impact on the quality of both commercial and public organizations. As a result, the enhancement of quality and the 
attempt to define and measure it are now major issues for higher education in many countries (Frazer (1992) as quoted in Willis and Taylor 1999).

\section{Quality in higher education}

It is necessary to determine what quality means to a particular set of customers and to design unique process to improve their satisfaction. Education is a service where the customer expresses satisfaction and dissatisfaction about school services and instructions. According to Menteru (2007) quality is defined as "fitness for purpose" that is, meeting or conforming to generally accepted standards. Quality implies a relative measure of inputs, processes, output or learning outcomes. Institutions, founders, and the public need some methods for obtaining assurance that the institution is keeping its promises to its stockholders. This is the primary goals of quality education. Students are said to be the primary customers of higher educational institutions. According to the survey carried out by Owlia and Aspinwall (1996), students received the highest rankings in terms of customer priority, followed by employers, society, faculty and facilities. Robinson, Poling, Akers, Galvin, Artzt and Allaire (1991) however, believe that the business community is the ultimate customer of the university's product. Hubbard (1994) resolved this conflict by considering an intermediate customer and the business community as the ultimate customer of the university's product. Referring to the employers as the customer, understanding the personal needs of business employers are necessary to make that assessment and enhance the quality of higher education graduates.

\section{Overview of company's needs}

Businesses require a broad blend of technical and strategic skills (Sheridan, 1993). Hence, there is no general consensus about what skills are needed by businesses and who possesses those skills (Cappelli, 1992). To solve this problem, several institutions have established a standard and routine procedure to survey businesses that hire their graduates (Rau, 1995). Schmidt (1991) conducted a survey and provided a list of nontechnical skills required from business graduates as creativity, communications, ethics entrepreneurship, globalization, information technology, interpersonal skills and problem solving. Levenburg (1996) supported the findings of the study by observing that problem analysis skills ranked high, along with oral communication, written communication, honesty and integrity, decision-making skills, reliability, self-initiative, computer skills, and leadership skills. The recent explosion of information technology, i.e internet usage clearly indicates the increasing importance on computer skills. A study by Hammond, Hartman and Brown (1996) reveals a surprisingly low percentage of college courses that require the study to work on computer-based applications despite the fact the businesses routinely rely on computer support to handle real-world operations. American Assembly of Collegiate schools of Business (AACSB) (1993) as quoted in Willis and Taylor (1999) strongly encouraged business schools to include written and oral communications as an important characteristic and provide coverage of ethical and global issues as well as the influence of political, social, legal and regulatory, environmental and technological issues.

Cook and finch (1994) surveyed which quality is viewed as most important to accounting recruiters. Their sample consisted of 2,000 randomly selected accounting employers representing public accounting, industry, government and education sectors. The study revealed that the most important quality in a potential employee is educational background, prior-work experience, training potential or others. The others included qualities such as peoples' skills, involvement in campus activities, strong managerial potential, intelligence, personality, common sense, ability to think and act decisively and ability to meet the demands of the profession. Oliver, Que, Farinacci, and Garland (1996) sited in Noor, Elham, Bahrain and Manaf (2000) surveyed the preferences of employers for the background of entry-level accountants. The results of the study revealed some deficiencies in accounting graduates' background qualifications. The areas included verifying computations by hand, and job and internship experiences, especially the ones involving computers. Many critics contend that higher education falls short in meeting the job requirements of industries. Parry, Ruthford, and Merrier (1996) observed that colleges and universities have been criticized for several shortcomings. A major criticism is that business schools put too much emphasis on analytical problem solving without regard to the practical implications of managerial actions and decisions. Businesses have also been critical of the lack of curriculum breadth and teaching quality. Maybe an even more important criticism is that too many colleges and universities have shifted from teaching students how to think to teaching what to think. Teaching the skills of logical analysis and systematic use of evidence so that students are able to examine ideas critically with factual information has been replaced by emotional interpretation constructs that are not based on reality (Sowell (1997) as quoted in Willis and Taylor (1999)). As a result, college graduates who enter the job market may have biased expectations about the level of performance required by industries. More specifically, businesses complain that too many students put their personal career before the goal of the organization (Hotch, 1992). This should not be unexpected given the changing employment environment of the present economy. 
Higher education should continually seek feedbacks from corporate friends to know how to adjust academic programs to meet changing job market requirements (Hotch, 1992). They should create a niche that exploits a unique strength to achieve a regional, if not a national reputation. This type of focusing is fundamental to every quality management programme.

\section{Quality Assurance in Accounting Education in Nigeria}

Business education involves teaching students the fundamentals, theories, and processes of business. Education in this field occurs at several levels. Secondary and higher education typically prepares students for an occupation in business or a business-related field, or a teaching career in academic.

At the graduate school level, students can seek a variety of specific degrees, most often Master in Business Administration (MBA). Students pursuing postgraduate degrees usually have some prior business experiences. In Nigeria there are numerous institutions, which are providing business education including public and private universities.

\section{Measuring the quality of education}

According to Okebukola (2006), quality of education can be measured based on several criteria like:

1. market demand of graduates

2. admission in foreign universities

3. research and publications

4. credit transfers

5. affiliations

\section{Methodology}

The research design adopted in this study was survey research design. Population, Sample and sampling procedure

The population consisted of all private and public companies respectively (Nigeria Stock Exchange). The sample population was made up of 225 and 125 private and public firms respectively. Seventy (70) respondents from both the private and the public sectors were randomly drawn from Edo, Delta, Anambra, PortHarcourt and Oyo states, giving a total sample population of 350 respondents.

\section{Instrument for data collection}

Copies of a well-structured questionnaire were used to elicit information from respondents. A pilot survey was conducted to test the validity and relevancy of the data collection instrument, with five companies. Validity of the instrument was based on the face and content values. Five point likert type scale consisting of 19 questions was used. Four hundred (400) copies of questionnaire were administered. Three fifty (350) copies were retuned. Fifty (50) copies were wrongly completed and so were totally removed from the study. Section A had four items on personal information of each of the respondents. Section B had nineteen items designed after the likert scale. The items elicited responses on attitude of employers from both the private and public companies on the quality of accounting graduates.

\section{Methods of Data Analysis}

The data collected were analyzed using simple frequencies, percentages rated mean and mean rankings. The frequencies were computed by tallying the number of responses to each variable. The percentage response to each variable was computed by dividing the frequencies with the number of respondents to the variable. The 5-point likert scale for the positively and negatively worded items was assigned numeric values as follows:

Reasonable extent $(\mathrm{RE}) \quad=5$

Considerable extent $(\mathrm{CE}) \quad=4$

Moderate extent $(\mathrm{ME}) \quad=3$

Little extent (LE) $\quad=2$

Negative or no extent $(\mathrm{N} / \mathrm{NE}) \quad=1$

The normative mean of the above scale was computed by adding the values of the response items on the 5 -point Likert scale i.e $5+4+3+2+1=15$ and divided by 5 to give a value of 3 . The weighted score was completed by first multiplying the number of response to each variable, with the rated response values on the 5point Likert scale and then summed up. The calculated weighted mean values were obtained by dividing the weighted score values by the number of respondents. Based on a rated mean of 3 , variables with mean values less than 3 were rejected while variables with mean values equal to and above 3 were accepted. The hypotheses were tested using the students' $t$-test at $95 \%$ level of significance with the aid of MINITAB student statistical software. 


\section{Result Presentation and Discussion}

The section below shows the presentation of results according to the research questions and hypotheses and the discussion of the results obtained from the study.

\section{Distribution of the companies by types}

Table 1 below shows the distribution of sampled companies by type. From the table, the private companies constitute a greater majority (65.71\%) of companies in the area as compared to public companies, which constitute only $34.29 \%$.

Table 1: Frequency Distribution of Companies by Types

\begin{tabular}{lll}
\hline Item & Frequency & Percentage (\%) \\
\hline Private companies & 225 & 65.71 \\
Public companies & 125 & 34.29 \\
\hline TOTAL & 350 & 100 \\
\hline
\end{tabular}

Source: Field Survey Data, (2013).

\section{Research Question 1:}

What is the public and private sectors perception of the quality of accounting graduates for skill requirements as produced by educational institutions?

Table 2: Public and Private Sectors Perception of Quality of Accounting Graduates as Produced by Educational Institutions

\begin{tabular}{|c|c|c|c|c|c|c|c|c|c|c|c|}
\hline $\begin{array}{l}\mathbf{S} / \\
\mathbf{N}\end{array}$ & Skills & Company Type & $\mathbf{R E}$ & $\mathbf{C E}$ & ME & LE & NE & NE & $\mathbf{T}$ & $\mathbf{N}$ & Decission \\
\hline 1 & Good personal attitude & Public company & 85 & 25 & 5 & 10 & - & 560 & 125 & 4.48 & Accepted \\
\hline 2 & $\begin{array}{lrr}\begin{array}{l}\text { Possession of } \\
\text { knowledge } \\
\text { performance }\end{array} & & \\
\end{array}$ & Public company & 20 & 60 & 25 & 20 & - & 455 & 125 & 3.64 & Accepted \\
\hline 3 & $\begin{array}{l}\text { Possession of computer } \\
\text { knowledge }\end{array}$ & Private company & 200 & 25 & - & - & - & 1100 & 225 & 4.88 & Accepted \\
\hline \multirow[t]{2}{*}{4} & \multirow{2}{*}{$\begin{array}{l}\text { Lack of knowledge to } \\
\text { carryout teamwork and } \\
\text { motivation. }\end{array}$} & Private company & 10 & 195 & 20 & - & - & 460 & 225 & 2.04 & Rejected \\
\hline & & Public company & 5 & 65 & 30 & 10 & 15 & 340 & 125 & 2.72 & Rejected \\
\hline \multirow[t]{2}{*}{5} & $\begin{array}{l}\text { Possession of skills in } \\
\text { written communication }\end{array}$ & Private company & 2.25 & - & - & - & - & 1125 & 225 & 5.00 & Accepted \\
\hline & & Public company & 115 & 5 & 3 & 2 & - & 608 & 125 & 4.86 & Accepted \\
\hline
\end{tabular}

\section{Source: Field Survey Date (2013)}

The above table shows the difference between the private and public employers perception of the quality of accounting graduates as produced by educational institutions. Based on the mean rating of 3.00 , the table shows that the companies perceived the graduates as possessing good personal attitude, general knowledge to job performance, computer knowledge, written communication skills and ability to manage projects. Lack of knowledge to carryout teamwork and motivation was

\section{Research Question 2:}

What are the skills most vital to accounting graduates as needed by employers?

Table 3: Mean Ranking of Most Vital Skills to Accounting Graduates as needed by Employers

\begin{tabular}{|l|l|l|l|l|l|l|l|l|l|l|l|}
\hline $\begin{array}{l}\text { S/ } \\
\text { N }\end{array}$ & Skills & $\begin{array}{l}\text { Reason } \\
\text { able } \\
\text { Extent } \\
(\mathbf{R e})\end{array}$ & $\begin{array}{l}\text { Conside } \\
\text { rable } \\
\text { Extent } \\
(\mathbf{C e})\end{array}$ & $\begin{array}{l}\text { Moderate } \\
\text { Extent } \\
\mathbf{( M e )}\end{array}$ & $\begin{array}{l}\text { Little } \\
\text { Extent } \\
\text { (Le) }\end{array}$ & $\begin{array}{l}\text { Negative } \\
\text { (N) }\end{array}$ & Total & $\mathbf{N}$ & $\mathbf{X}$ & Decision & $\begin{array}{l}\text { Ran } \\
\text { king }\end{array}$ \\
\hline 1 & $\begin{array}{l}\text { Appearances is } \\
\text { zero }\end{array}$ & - & - & - & 10 & 340 & 1740 & 350 & 4.97 & Accepted & $1^{\text {st }}$ \\
\hline 2 & $\begin{array}{l}\text { Ability to write } \\
\text { written } \\
\text { communication }\end{array}$ & 340 & 5 & 3 & 2 & - & 1733 & 350 & 4.93 & Accepted & $2^{\text {nd }}$ \\
\hline 3 & $\begin{array}{l}\text { Computer } \\
\text { knowledge }\end{array}$ & 300 & 50 & - & - & - & 1700 & 350 & 4.85 & Accepted & $3^{\text {rd }}$ \\
\hline 4 & $\begin{array}{l}\text { Awarenes on } \\
\text { global issues }\end{array}$ & 300 & 45 & 5 & - & - & 1695 & & 4.84 & Accepted & $4^{\text {th }}$ \\
\hline 5 & $\begin{array}{l}\text { Lack of work } \\
\text { based experience }\end{array}$ & 290 & 30 & 20 & 10 & - & 1650 & 350 & 4.71 & Accepted & $5^{\text {th }}$ \\
\hline 6 & No intrinsic & 240 & 60 & 30 & 20 & - & 1570 & 350 & 4.48 & Accepted & $6^{\text {th }}$ \\
\hline
\end{tabular}




\begin{tabular}{|c|c|c|c|c|c|c|c|c|c|c|c|}
\hline & $\begin{array}{l}\text { skills } \\
\text { (interpersonal } \\
\text { skills) }\end{array}$ & & & & & & & & & & \\
\hline 7 & $\begin{array}{l}\text { Ability to } \\
\text { perform assigned } \\
\text { tasks }\end{array}$ & 240 & 60 & 30 & 20 & - & 1570 & 350 & 4.48 & Accepted & $6^{\text {th }}$ \\
\hline 8 & $\begin{array}{l}\text { Discipline and } \\
\text { ready to take } \\
\text { correction }\end{array}$ & 250 & 40 & 38 & 17 & 5 & 1563 & 350 & 4.46 & Accepted & $8^{\text {th }}$ \\
\hline 9 & Problem solving & 220 & 80 & 30 & 20 & - & 1550 & 350 & 4.43 & Accepted & $9^{\text {th }}$ \\
\hline 10 & $\begin{array}{l}\text { Personnel } \\
\text { attitudinal }\end{array}$ & 200 & 100 & 25 & 25 & - & 1525 & 330 & 4.35 & Accepted & $10^{\text {th }}$ \\
\hline 11 & $\begin{array}{l}\text { Knowledge and } \\
\text { standards can be } \\
\text { linked to } \\
\text { outcomes and } \\
\text { skills needed by } \\
\text { labour market. }\end{array}$ & 55 & 280 & 10 & 5 & - & 1435 & 350 & 4.11 & Accepted & $11^{\text {th }}$ \\
\hline 12 & $\begin{array}{l}\text { Lack of oral } \\
\text { communication } \\
\text { expression. }\end{array}$ & 55 & 280 & 10 & 5 & - & 1435 & 350 & 4.11 & Accepted & $11^{\text {th }}$ \\
\hline 13 & $\begin{array}{l}\text { General } \\
\text { knowledge } \\
\text { perform job }\end{array}$ & 55 & 160 & 85 & 50 & - & 1270 & 350 & 3.63 & Accepted & $13^{\text {th }}$ \\
\hline 14 & $\begin{array}{l}\text { Ability to handle. } \\
\text { Project } \\
\text { management }\end{array}$ & 50 & 180 & 75 & 40 & 10 & 1285 & 350 & 3.60 & Accepted & $14^{\text {th }}$ \\
\hline 15 & Leadership & 5 & 10 & 250 & 60 & 25 & 960 & 350 & 2.7 & Accepted & $15^{\text {th }}$ \\
\hline 16 & $\begin{array}{lr}\text { Lack } & \text { of } \\
\text { knowledge } & \text { to } \\
\text { carryout } & \\
\text { teamwork } & \text { and } \\
\text { motivation. } & \\
\end{array}$ & 15 & 260 & 50 & 10 & 15 & 800 & 350 & 2.28 & & $16^{\text {th }}$ \\
\hline 17 & Lack of initiative & 10 & 230 & 40 & 35 & 35 & 905 & 350 & 2.28 & Rejected & $16^{\text {th }}$ \\
\hline 18 & $\begin{array}{l}\text { Lack of } \\
\text { knowledge as per } \\
\text { the accounting } \\
\text { principles and } \\
\text { procedure }\end{array}$ & 40 & 250 & 35 & 15 & 10 & 755 & 350 & 2.15 & Rejected & $18^{\text {th }}$ \\
\hline 19 & $\begin{array}{l}\text { Knowledge of } \\
\text { other related } \\
\text { disciplines }\end{array}$ & 50 & 240 & 40 & 10 & 10 & 740 & 350 & 2.11 & Rejected & $19^{\text {th }}$ \\
\hline
\end{tabular}

Source: Field Survey Data (2013)

The table above reveals the most vital skills to accounting graduate as needed by employers of both the private and public companies. These skills include appearances, written communication, computer knowledge, awareness on global issues and work based experiences.

\section{Research Question 3}

What are employers' perceptions of the differences in skills acquisition among the accounting graduates?

Table 4: Mean Ranking of the Perception of Employers of the Quality of Accounting Graduates

\begin{tabular}{|c|c|c|c|c|c|c|c|c|c|c|c|}
\hline $\mathbf{S} / \mathbf{N}$ & Skills & $\begin{array}{l}\text { Reasona } \\
\text { ble } \\
\text { Extent } \\
\text { (Re) } \\
\end{array}$ & $\begin{array}{l}\text { Consider } \\
\text { able } \\
\text { Extent } \\
\text { (Ce) } \\
\end{array}$ & $\begin{array}{l}\text { Moderate } \\
\text { Extent } \\
\text { (Me) }\end{array}$ & $\begin{array}{l}\text { Little } \\
\text { Exten } \\
\text { t (Le) }\end{array}$ & $\begin{array}{l}\text { Negative } \\
\text { (N) }\end{array}$ & $\begin{array}{l}\text { Tot } \\
\text { al }\end{array}$ & $\mathbf{N}$ & $\mathbf{X}$ & Decision & $\begin{array}{l}\text { Ran } \\
\text { king }\end{array}$ \\
\hline 1 & $\begin{array}{ll}\begin{array}{l}\text { Possession } \\
\text { general }\end{array} & \text { of } \\
\text { knowledge } \\
\text { perform job }\end{array}$ & 55 & 160 & 85 & 50 & - & $\begin{array}{l}127 \\
0\end{array}$ & 350 & 3.63 & Accepted & $11^{\text {th }}$ \\
\hline 2 & $\begin{array}{l}\text { Lack of work } \\
\text { based experience }\end{array}$ & 290 & 30 & 20 & 10 & - & $\begin{array}{l}165 \\
0 \\
\end{array}$ & 350 & 4.71 & Accepted & $4^{\text {th }}$ \\
\hline 3 & $\begin{array}{lr}\text { Lack } & \text { of } \\
\text { knowledge } & \text { in } \\
\text { accounting } & \\
\text { principles } & \text { and } \\
\text { procedures } & \\
\end{array}$ & 40 & 250 & 35 & 15 & 10 & 755 & 350 & 2.15 & Rejected & $16^{\text {th }}$ \\
\hline 4 & $\begin{array}{lr}\text { Knowledge and } \\
\text { standards can be } \\
\text { linked } & \text { to } \\
\text { outcomes and } \\
\text { skills needed by } \\
\text { labour market. }\end{array}$ & 55 & 280 & 10 & 5 & - & $\begin{array}{l}143 \\
5\end{array}$ & 350 & 4.11 & Accepted & $14^{\text {th }}$ \\
\hline
\end{tabular}


Quality of Accounting Graduates: A Survey of Employers in Nigeria

\begin{tabular}{|c|c|c|c|c|c|c|c|c|c|c|c|}
\hline 5 & $\begin{array}{l}\text { Ability to perform } \\
\text { assigned tasks }\end{array}$ & 240 & 60 & 30 & 20 & - & $\begin{array}{l}157 \\
0\end{array}$ & 350 & 4.48 & Accepted & $5^{\text {th }}$ \\
\hline 6 & $\begin{array}{l}\text { Good personnel } \\
\text { attitude }\end{array}$ & 200 & 100 & 25 & 25 & - & $\begin{array}{l}152 \\
5\end{array}$ & 330 & 4.35 & Accepted & $9^{\text {th }}$ \\
\hline 7 & Lack of initiative & 10 & 230 & 40 & 35 & 35 & 905 & 350 & 2.28 & Accepted & $18^{\text {th }}$ \\
\hline 8 & $\begin{array}{l}\text { Computer } \\
\text { knowledge }\end{array}$ & 300 & 50 & - & - & - & $\begin{array}{l}170 \\
0\end{array}$ & 350 & 4.85 & Accepted & $3^{\text {rd }}$ \\
\hline 9 & Problem solving & 220 & 80 & 30 & 20 & - & $\begin{array}{l}155 \\
0\end{array}$ & 350 & 4.43 & Accepted & $8^{\text {th }}$ \\
\hline 10 & $\begin{array}{lr}\text { Lack } & \text { of } \\
\text { knowledge } & \text { to } \\
\text { carryout } \\
\text { teamwork } \\
\text { motivation. }\end{array}$ & 15 & 260 & 50 & 10 & 15 & 800 & 350 & 2.28 & & $15^{\text {th }}$ \\
\hline 11 & $\begin{array}{l}\text { Possession of } \\
\text { skills written } \\
\text { communication }\end{array}$ & 340 & 5 & 3 & 2 & - & $\begin{array}{l}173 \\
3\end{array}$ & 350 & $\begin{array}{l}4.93 \\
2\end{array}$ & Accepted & $2^{\text {nd }}$ \\
\hline 12 & $\begin{array}{l}\text { Lack of oral } \\
\text { communication } \\
\text { expression. }\end{array}$ & 55 & 280 & 10 & 5 & - & $\begin{array}{l}143 \\
5\end{array}$ & 350 & 4.11 & Accepted & $10^{\text {th }}$ \\
\hline 13 & $\begin{array}{l}\text { Ability to handle } \\
\text { project } \\
\text { management }\end{array}$ & 50 & 180 & 75 & 40 & 10 & $\begin{array}{l}128 \\
5\end{array}$ & 350 & 3.60 & Accepted & $12^{\text {th }}$ \\
\hline 14 & $\begin{array}{l}\text { Knowledge } \begin{array}{r}\text { of } \\
\text { other related } \\
\text { disciplines }\end{array} \\
\end{array}$ & 50 & 240 & 40 & 10 & 10 & 740 & 350 & 2.11 & Accepted & $17^{\text {th }}$ \\
\hline 15 & $\begin{array}{l}\text { Awareness } \\
\text { global issues }\end{array}$ & 300 & 45 & 5 & - & - & $\begin{array}{l}169 \\
5\end{array}$ & & 4.84 & & \\
\hline 16 & $\begin{array}{l}\text { Appearances is } \\
\text { zero }\end{array}$ & - & - & - & 10 & 340 & $\begin{array}{l}174 \\
0\end{array}$ & 350 & 4.97 & Accepted & $1^{\text {st }}$ \\
\hline 17 & $\begin{array}{l}\text { No intrinsic skills } \\
\text { (interpersonal } \\
\text { skills) }\end{array}$ & 240 & 60 & 30 & 20 & - & $\begin{array}{l}157 \\
0\end{array}$ & 350 & 4.48 & Accepted & $5^{\text {th }}$ \\
\hline 18 & Leadership & 5 & 10 & 250 & 60 & 25 & 960 & 350 & 2.7 & Accepted & $13^{\text {th }}$ \\
\hline 19 & $\begin{array}{ll}\text { Discipline } & \text { and } \\
\text { ready to take } \\
\text { correction }\end{array}$ & 250 & 40 & 38 & 17 & 5 & $\begin{array}{l}156 \\
3\end{array}$ & 350 & 4.46 & Accepted & $7^{\text {th }}$ \\
\hline
\end{tabular}

Source: Field Survey Data (2013)

From table 4 above, the first five skills with highest mean scores are appearance of accounting graduates, written communication, computer knowledge, lack of work based experience and ability to perform assigned task. Three skills with lowest mean scores are lack of knowledge in accounting procedures and principles, lack of initiatives and other related discipline. From these findings, it shows that some higher educational institutions do not seem to prepare graduates with all skills required by employers in the business world.

\section{Research Hypotheses}

Hypothesis 1

$\mathbf{H}_{\mathbf{0 1}}$ : There is no significant difference between private and public employers' perceptions of the quality of accounting graduates.

Table 5: Mean Rating, Standard Deviation (SD), t-values and p-value for Employers' Perception of Quality among Accounting Graduates. $\left(\mathrm{N}_{1},=225, \mathrm{~N}_{2}=123, \mathrm{df}=348, \mathrm{p}\right.$-value $\left.=0.05\right)$

\begin{tabular}{|c|c|c|c|c|c|c|c|c|}
\hline $\mathbf{S} / \mathbf{N}$ & SKILLS & $\mathbf{X}_{1}$ & $\mathbf{X}_{2}$ & SD $_{1}$ & $\mathbf{S D}_{2}$ & t-cal & p-value & Decision \\
\hline 1 & Personal attitudinal & 4.28 & 4.48 & 47.7 & 36.8 & 5.08 & 0.000 & Significant \\
\hline 2 & General knowledge to perform job & 3.62 & 3.64 & 32.0 & 19.31 & 7.98 & 0.000 & Significant \\
\hline 3 & Computer knowledge & 4.88 & 4.80 & 123.7 & 53.0 & 4.30 & 0.000 & Significant \\
\hline 4 & $\begin{array}{l}\text { Lack of knowledge to carryout team } \\
\text { work and mutation }\end{array}$ & 2.04 & 2.72 & 104.4 & 22.5 & 5.09 & 0.000 & Significant \\
\hline 5 & Ability to write Written communication & 5.00 & 4.86 & 0.000 & 5.58 & 52.11 & 0.000 & Significant \\
\hline 6 & Ability to Project management & 3.68 & 3.64 & 43.9 & 19.3 & 3.57 & 0.000 & Significant \\
\hline
\end{tabular}

Source: Field Survey Data (2013)

The table above represents variables on employers' perception of quality of accounting graduates. All the variables (1-6) have p-value less than 0.05. The null hypothesis for the variable was therefore rejected and the alternative accepted i.e., there is significant difference between private and public employers' perception of quality among accounting graduates. 


\section{Hypothesis 2}

$\mathbf{H}_{\mathbf{0} 2}$ : There is no significant difference between the quality of accounting graduates needed by the private and public employers in Nigeria.

Tables 6: Mean Rating, Standard Deviation (SD), t-value and p-value for Quality of Accounting Graduates needed by Private and Public Employers. $\left(\mathrm{N}_{1},=225, \mathrm{~N}_{2}=125, \mathrm{df}=348\right.$, $\mathrm{p}$-value $\left.=0.05\right)$.

\begin{tabular}{|l|l|l|l|l|l|l|l|l|}
\hline $\mathbf{S} / \mathbf{N}$ & SKILLS & $\mathbf{X}_{\mathbf{1}}$ & $\mathbf{X}_{\mathbf{2}}$ & $\mathbf{S}_{\mathbf{1}} \mathbf{D}_{\mathbf{1}}$ & $\mathbf{S}_{\mathbf{2}} \mathbf{D}_{\mathbf{2}}$ & $\mathbf{t}$-cal & $\mathbf{p}$-value & Remark \\
\hline 1 & Lack of initiative & 2.6 & 2.55 & 83.7 & 46.6 & 3.08 & 0.002 & Sign \\
\hline 2 & $\begin{array}{l}\text { Knowledge and standards can be linked } \\
\text { to out comes and skills needed by labour } \\
\text { market. }\end{array}$ & 4.09 & 4.10 & 59.2 & 31.3 & 3.51 & 0.000 & Sign \\
\hline
\end{tabular}

Source: Field Survey Data (2013)

The table above shows variables on employers' perception of quality of accounting graduates needed by private and public company in Nigeria. The variables $1-2$ have p-value of 0.002 and 0.001 , which are less than 0.05 . The null hypothesis for variables was rejected and the alternative accepted, i.e. there is significant difference between the quality of accounting graduates needed by the private and public employers in Nigeria.

\section{Hypothesis three:}

$\mathbf{H}_{\mathbf{0} 3}$ : There is no significant difference between the skills that are most vital to accounting graduates as perceived by the private and public employers.

Table 7: Mean Rating, Standard Deviation (SD), t-values and p-value for Difference in Skills Most Vital to Accounting Graduates. $\left(\mathrm{N}_{1},=225, \mathrm{~N}_{2}=123, \mathrm{df}=348\right.$, p-value $\left.=0.05\right)$

\begin{tabular}{|l|l|l|l|l|l|l|l|l|}
\hline $\mathbf{S} / \mathbf{N}$ & SKILLS & $\mathbf{X}_{\mathbf{1}}$ & $\mathbf{X}_{\mathbf{2}}$ & $\mathbf{S D}_{\mathbf{1}}$ & $\mathbf{S D}_{\mathbf{2}}$ & $\mathbf{t}$-cal & p-value & Decision \\
\hline 1 & Lack of work based experience & 4.75 & - & 89.4 & - & -6.49 & 0.000 & Significant \\
\hline 2 & Computer knowledge & 4.88 & 4.80 & 1.24 & 53.0 & 4.30 & 0.000 & Significant \\
\hline 3 & $\begin{array}{l}\text { Problem solving } \\
4\end{array}$ & - & 4.68 & 32.0 & - & -21.38 & 0.000 & Significant \\
& $\begin{array}{l}\text { Possession of skills in written } \\
\text { communication }\end{array}$ & 5.00 & 4.86 & 1.00 & 50.3 & 59.69 & 0.000 & Significant \\
\hline 5 & Awareness of global issues & 4.86 & 4.80 & 10.9 & 53.0 & 1.26 & 0.209 & Significant \\
\hline 6 & Appearance is zero & 4.97 & - & 1.00 & 1.00 & 0.00 & 1.000 & Not Sign \\
\hline
\end{tabular}

Source: Field Survey Data $(2013$

The table above shows variables on differences between the skills that are most vital to accounting graduates as perceived by the private and public employers. The variables 1-5 have p-value of less than 0.05 while variable $6 \mathrm{p}$-value of greater than 0.05 . Therefore, the null hypothesis is rejected based on variables 1-5 and the alternative accepted, i.e. there is significant difference between the quality of accounting graduates needed by the private and public employers in Nigeria. Based on variable 6, the null hypothesis can be accepted and the alternative rejected i.e. there is no significant difference between the quality of accounting graduates needed by the private and public employers in Nigeria.

\section{Discussion of findings}

The finding from the study reveals that five top skills that show the highest mean score are appearance of accounting graduates, work based experienced, ability to perform assigned task, ability to written communication and three skill with lowest mean scores are lack of knowledge as per accounting procedures and principles, lack of initiative and other related discipline, which shows that higher education institution do not seems to prepare accounting graduates with skills required by business. The finding shows that today's accounting graduates are computer literate that is they are well equipped with computer knowledge and moreso the accounting graduates appearance is reasonable and have experience in ability to perform tasks and written communication. Further more the finding also reveal three skills with lowest mean scores. There are lack of knowledge as per accounting.

Secondly, the study also revealed that institution do not provide the skill that most vital to accounting graduate by employer i.e variables 1-5 shows there is significant different between employers' perception from the private and public company toward higher education institution preparedness in providing graduate with all the skills needed by employers, variable 6 shows there is no significant difference between the quality of accounting graduates needed by the private and public employers in Nigeria. The study supported Rosamath against the one found in the difference may be due to the lack of Nigerian commitment among higher education institution to revise and update changes in the business environment and requirements. The study also investigates to identify the employers' perception towards the quality of accounting graduates from public and private higher education institutions. The respondents under the private company show, $2.60 \%$ while under the public company show $4.10 \%$ perceived that there are quality differences among the accounting graduates. This 
may due to lack of knowledge as per accounting principles and procedure, ability to perform assigned tasks and knowledge of other related discipline. This study revealed further affirmed of the study of Rosmawati (2000) and against with the found in Wallis and Taylor (1999) stating the difference may be due to lack of commitment among Nigeria Higher Institution to revise and update their curriculum to reflect the rapid changes in the business environment and requirements. Bennis and Toole (2009) revealed that generally accounting curriculum needs to be update; the findings supported further researchers findings such as Rosmawati (2000) and Azizi, Elham, Bahrain \& Manaf (2000).

Thirdly, the study also investigates to identify the employers' perception toward the quality of accounting graduates from public and private higher education institution. The respondents under the private company show $2.6 \%$ while under the public company show $4.10 \%$ thereby perceived that there are quality differences among the accounting graduates, this may be due to lack of knowledge as per accounting principle and procedure, ability to perform assigned task and knowledge of other related discipline. this study revealed further affirmed of the study of Ranasingle (1992) and Lindsay (2002) who acknowledged that a gap still exist between the level of skills acquired by accounting graduates and the entry level work requirement. In the field work, the result is also similar with that of Ahmed (2006) who reported that the emergence of skill gap in the employer/graduates interface in giving extra pressure on doubts in employers and Accounting education graduates interface in the Nigeria labour market. Senior (2009) also revealed that globalization and economic recession are introducing extra pressure on accounting education graduates in relation to the large number of job losses around the world.

\section{Conclusion}

The study attempted to find out quality of accounting graduates as perceive by the employers in Nigeria. Five tops skills with different mean score were appearances of Accounting graduates, written communication, computer knowledge, lack of work based experience and ability to perform assigned tasks. The study also review the weakness mean score that is lack of knowledge as per accounting procedure and principles. Lack of initiatives and other related discipline. Furthermore, the study also investigate whether the institution provide the skills that are most vital to accounting graduates which show there is significance difference between the employers perception for both private and public company toward quality of Accounting graduates, that is some of higher education institution do not seem to prepare graduate with all skills requirement by business. The major conclusion of the study is that Nigerian have expressed concern about the need to improve quality of tertiary institutions, the need too reassure the public about the quality of accounting graduates and the importance of ensuring that tertiary education offered and meets acceptable local and intentional standards, and to make a significant contribution to economic growth, hence improve, prepare the Nigerian graduates (Accounting) to meet the skills requirements needed by the employer in Nigeria.

\section{Recommendation}

Based on the above conclusion the following recommendations are thereby made.

1. Higher education institution and Agency of education should review Accounting curriculum often that will emphasize on relevant skills and competences. This will help the institution to take vital initiation to review the attributes and skill needed by the accounting graduates.

2. National Universities Commission and other agency should or rub in mind (relationship) with the businesses to get the latest input of the business development any requirement. This can be achieved through educational product and by conducting and developing community training work shop. This is important on the students depend upon their instructors to be current in knowledge of the market place and to provide them with the possible education.

3. Higher education institution should also lengthen the period of practical training to give more exposure to the study of real business world.

4. The future accounting education will have to constantly keep update on new skills needed by the accounting graduates. That is their should be new certificate requirement for future Accounting education teachers which require adequate training.

\section{References}

[1]. Adamu and Dandago (2013). Assessment of Views of business education graduates on the effect of technological advancement on their employment in Nigeria labour market. International Journal of Academic Research in Progressive Education and Development, 2(3).

[2]. Ahmed, I. (2009). Guide to career development in Nigeria. Unpublished paper presentation at Career Day held at Government Secondary School Gadabuke on 20 August.

[3]. Aziza, Elham, Bahrain, and Manaf (2000). Employers perception of the quality of accounting graduates in Malaysia: A paper presented at the seminar on Accounting and Information Technology Convention Center, University Utara Malaysia.

[4]. Bennis, W.G. and O'Toole, J. (2005). How business schools lost their way. Harvard business review, 82(5). 
[5]. Cook, E.D. and Finch, B. (1994). Qualities employers seek in new accounting employees. Journal of Education for Business, 71, pp.263-266.

[6]. Hotch, R. (1992). This is not your father's MBA. Nation's Business, 80 pp.51-52.

[7]. Levenburg, N.M. (1996). General management skills: Do practitioners and academic faculty agree on their importance? Journal of Education for business, PP.47-81.

[8]. Linsay, C. (2002). Long-term unemployment and the "employability gap": Priorities for renewing Britain's new deal. Journal of European Industrial Training, 26(9), 411-419.

[9]. Materu, P. (2007). Higher education quality assurance in sub-saharan African; status, challenges opportunities and promising practice. The World bank Washington, D.C: Africa.

[10]. Okebukola, P. (2006). "Quality assurance in higher education: The Nigerian experience" Paper Presented at the Quality Assurance Tertiary Education Conference Service France, June 18.

[11]. Oliver, T.W., Que, A.L. Farinch, C.S, and Garland, B.C. (1996). Employers preferences for the background of entry-level accountants: Degree, certification, verification, internship, experience, Journal of Education for Business, pp. 82-85.

[12]. Parry, L.E., Ruthford, L., and Merrier, P.A. (1996). Too little, too late: Are business schools falling behind the times? Journal of Education for Business, 71, pp.293-299.

[13]. Porwal I. (2006). Accounting theory: An Introduction ( $3^{\text {rd }}$ edition) New Delhi India: Tata Mc. Graw-Hill publishing company.

[14]. Rosmawati, Mamat (2000). Employers Perception of the Quality of the Malaysian Business Graduates, Unpublished Master's Thesis, University Utara Malaysia.

[15]. Schmidt, S. (1991). Marketing alumi perspective on the educational challenges for the 1990's, Marketing Education Review, 1, pp.24-33.

[16]. Senior, Z. (2009). Challenges of Labour Market on graduates in $21^{\text {st }}$ century: Unpublished.

[17]. Singh, GK.G., \& Singh, S.K.G. (2008). Malaysian graduates employability skills. UniTAR e-Journal, 4(1), 15-45.

[18]. Todaro, M.P and Smith, S.C. (2009), Economics development (10 ${ }^{\text {th }}$ Ed.) London: Adison Wesley.

[19]. Williamson, I.P. (2000): Land Administration and Cadastral Trends. Technical Papers of N/FIG Conference on Land Tenure and Cadastral Infrastructures for Sustainable Development, pp. 317-338. Melbourne, Australia, October, 1999.

[20]. Willis, T.H. \& Taylor, A.J. (1999). Total quality management and higher education: employer's perspective. Total Quality Management, 10(7), pp.997.

\section{APPENDIX}

INSTRUCTION: This questionnaire is in two parts. Part A contains 4 items only on your personal data. Part B contains 28 statements to which you should respond with a tick each. Reasonable Extent (RE) Considerable Extent (CE) Moderate Extent (ME) Little Extent (LE) Negative (N). Please note that each statement should have only one tick.

\section{PART A (PERSONAL DATA)}

Tick the one that is more appropriate to you.
(a)
(b) age: 20-30 ( ) 31-40( ) 41 and above ( )
Name of your Organization

(c) How long have you been working in your present job?

Less than 5years ( ) 6-15years ( ) 15years and above ( )

(d) Educational Qualification

a. Polytechnic/University

b. professional/Chartered Accounting

c. Others

\section{SECTION B}

\begin{tabular}{|c|c|c|c|c|c|c|}
\hline $\mathbf{S} / \mathbf{N}$ & Skills & $\begin{array}{l}\text { Reasonable } \\
\text { Extent (Re) }\end{array}$ & $\begin{array}{l}\text { Considerable } \\
\text { Extent (Ce) }\end{array}$ & $\begin{array}{l}\text { Moderate } \\
\text { Extent (Me) }\end{array}$ & $\begin{array}{l}\text { Little Extent } \\
\text { (Le) }\end{array}$ & $\begin{array}{l}\text { Negative } \\
\text { (N) }\end{array}$ \\
\hline 1 & General knowledge to perform job & & & & & \\
\hline 2 & Lack of work based experience & & & & & \\
\hline 3 & $\begin{array}{l}\text { Lack of knowledge as per the } \\
\text { accounting principles and procedure }\end{array}$ & & & & & \\
\hline 4 & $\begin{array}{l}\text { Knowledge and standards can be linked } \\
\text { to outcomes and skills needed by labour } \\
\text { market. }\end{array}$ & & & & & \\
\hline 5 & Ability to perform assigned tasks & & & & & \\
\hline 6 & Personnel attitudinal & & & & & \\
\hline 7 & Lack of initiative & & & & & \\
\hline 8 & Computer knowledge & & & & & \\
\hline 9 & Problem solving & & & & & \\
\hline 10 & $\begin{array}{l}\text { Lack of knowledge to carryout } \\
\text { teamwork and motivation. }\end{array}$ & & & & & \\
\hline 11 & $\begin{array}{l}\text { Ability to } \\
\text { communication }\end{array}$ & & & & & \\
\hline 12 & $\begin{array}{l}\text { Lack of oral communication } \\
\text { expression. }\end{array}$ & & & & & \\
\hline 13 & Ability to Project management & & & & & \\
\hline 14 & Knowledge of other related disciplines & & & & & \\
\hline 15 & Awareness on global issues & & & & & \\
\hline
\end{tabular}


Quality of Accounting Graduates: A Survey of Employers in Nigeria

\begin{tabular}{|l|l|l|l|l|l|}
\hline 16 & Appearances is zero & & & \\
\hline 17 & No intrinsic skills (interpersonal skills) & & & & \\
\hline 18 & Leadership & & & & \\
\hline 19 & Discipline and ready to take correction & & & & \\
\hline
\end{tabular}

\section{0/23/2013 12:16:18 AM}

Descriptive Statistics: PSP, PUSP

Variable Mean StDev

$\begin{array}{lll}\text { PSP } & 56.3 & 47.7\end{array}$

PUSP $\quad 31.3 \quad 36.8$

Two-Sample T-Test and CI

Sample N Mean StDev SE Mean

$\begin{array}{lllll}1 & 225 & 56.3 & 47.7 & 3.2\end{array}$

$\begin{array}{lllll}2 & 125 & 31.3 & 36.8 & 3.3\end{array}$

Difference $=\mathrm{mu}(1)-\mathrm{mu}(2)$

Estimate for difference: 25.0000

95\% CI for difference: $(15.3185,34.6815)$

T-Test of difference $=0($ vs not $=):$ T-Value $=5.08 \mathrm{P}$-Value $=0.000 \mathrm{DF}=348$

Both use Pooled StDev $=44.1260$

Descriptive Statistics: PSP_1, PUSP_1

Variable Mean StDev

PSP $1156.3 \quad 32.0$

PUSP_1 31.2519 .31

\section{Two-Sample T-Test and CI}

Sample N Mean StDev SE Mean

$\begin{array}{lllll}1 & 225 & 56.3 & 32.0 & 2.1\end{array}$

$\begin{array}{lllll}2 & 125 & 31.3 & 19.3 & 1.7\end{array}$

Difference $=\mathrm{mu}(1)-\mathrm{mu}(2)$

Estimate for difference: 25.0500

95\% CI for difference: $(18.8754,31.2246)$

T-Test of difference $=0($ vs not $=):$ T-Value $=7.98 \mathrm{P}$-Value $=0.000 \mathrm{DF}=348$

Both use Pooled StDev $=28.1423$

Descriptive Statistics: PSP_2, PUSP_2

Variable Mean StDev

PSP $2 \quad 112.5 \quad 123.7$

PUSP_2 $62.5 \quad 53.0$

Two-Sample T-Test and CI

Sample N Mean StDev SE Mean

$\begin{array}{lllll}1 & 225 & 113 & 124 & 8.2\end{array}$

$\begin{array}{lllll}2 & 125 & 62.5 & 53.0 & 4.7\end{array}$

Difference $=\mathrm{mu}(1)-\mathrm{mu}(2)$

Estimate for difference: 50.0000

95\% CI for difference: $(27.1456,72.8544)$

T-Test of difference $=0($ vs not $=):$ T-Value $=4.30 \mathrm{P}$-Value $=0.000 \mathrm{DF}=348$

Both use Pooled StDev $=104.1646$

Descriptive Statistics: PSP_3, PUSP_3

Variable Mean StDev

$\begin{array}{llll}\text { PSP } 3 & 75.0 & 104.0\end{array}$

PUSP_3 $27.0 \quad 22.5$

\section{Two-Sample T-Test and CI}


Sample N Mean StDev SE Mean

$\begin{array}{lllll}1 & 225 & 75 & 104 & 6.9\end{array}$

$\begin{array}{lllll}2 & 125 & 27.0 & 22.5 & 2.0\end{array}$

Difference $=\mathrm{mu}(1)-\mathrm{mu}(2)$

Estimate for difference: 48.0000

95\% CI for difference: $(29.4574,66.5426)$

$\mathrm{T}$-Test of difference $=0($ vs not $=): \mathrm{T}$-Value $=5.09 \mathrm{P}$-Value $=0.000 \mathrm{DF}=348$

Both use Pooled StDev $=84.5128$

Descriptive Statistics: PSP_4, PUSP_4

Variable Mean StDev

PSP $4 \quad 225.00$

PUSP $4 \quad 31.3 \quad 55.8$

Two-Sample T-Test and CI

Sample N Mean StDev SE Mean

$\begin{array}{lllll}1 & 225 & 225.00 & 1.00 & 0.067\end{array}$

$\begin{array}{lllll}2 & 125 & 31.3 & 55.8 & 5.0\end{array}$

Difference $=\mathrm{mu}(1)-\mathrm{mu}(2)$

Estimate for difference: 193.700

95\% CI for difference: $(186.390,201.010)$

T-Test of difference $=0($ vs not $=):$ T-Value $=52.11 \mathrm{P}-$ Value $=0.000 \mathrm{DF}=348$

Both use Pooled StDev $=33.3182$

Descriptive Statistics: PSP_5, PUSP_5

Variable Mean StDev

PSP $5 \quad 46.0 \quad 43.9$

PUSP $5 \quad 31.2519 .31$

Two-Sample T-Test and CI

Sample N Mean StDev SE Mean

$\begin{array}{lllll}1 & 225 & 46.0 & 43.9 & 2.9\end{array}$

$\begin{array}{lllll}2 & 125 & 31.3 & 19.3 & 1.7\end{array}$

Difference $=\mathrm{mu}(1)-\mathrm{mu}(2)$

Estimate for difference: 14.7500

95\% CI for difference: $(6.6190,22.8810)$

T-Test of difference $=0($ vs not $=):$ T-Value $=3.57 \mathrm{P}$-Value $=0.000 \mathrm{DF}=348$

Both use Pooled StDev $=37.0590$

Descriptive Statistics: PSP 7, PUSP 8

Variable Mean StDev

$\begin{array}{lll}\text { PSP } 7 & 56.3 & 83.7\end{array}$

PUSP $8 \quad 31.3 \quad 46.6$

Two-Sample T-Test and CI

Sample N Mean StDev SE Mean

$\begin{array}{lllll}1 & 225 & 56.3 & 83.7 & 5.6\end{array}$

$\begin{array}{lllll}2 & 125 & 31.3 & 46.6 & 4.2\end{array}$

Difference $=\mathrm{mu}(1)-\mathrm{mu}(2)$

Estimate for difference: 25.0000

95\% CI for difference: $(9.0523,40.9477)$

$\mathrm{T}$-Test of difference $=0($ vs not $=):$ T-Value $=3.08 \mathrm{P}-$ Value $=0.002 \mathrm{DF}=348$

Both use Pooled StDev $=72.6855$

\section{0/23/2013 12:23:29 AM}

Worksheet size: 10000 cells.

Welcome to Minitab, press F1 for help.

Retrieving project from file: 'C: Program Files $\backslash$ MINITAB 14 
Student|Studnt14\AFOLABI.MPJ'

Descriptive Statistics: PSP_6, PUSP_6

Variable Mean StDev

$\begin{array}{lll}\text { PSP } 6 & 45.0 & 59.2\end{array}$

PUSP_6 $\quad 25.0 \quad 31.3$

Two-Sample T-Test and CI

Sample N Mean StDev SE Mean

$\begin{array}{lllll}1 & 225 & 45.0 & 59.2 & 3.9\end{array}$

$\begin{array}{lllll}2 & 125 & 25.0 & 31.3 & 2.8\end{array}$

Difference $=\mathrm{mu}(1)-\mathrm{mu}(2)$

Estimate for difference: 20.0000

95\% CI for difference: $(8.8018,31.1982)$

T-Test of difference $=0($ vs not $=):$ T-Value $=3.51 \mathrm{P}$-Value $=0.001 \mathrm{DF}=348$

Both use Pooled StDev $=51.0387$

\section{0/23/2013 2:44:55 AM}

Worksheet size: 10000 cells.

Welcome to Minitab, press F1 for help.

Retrieving project from file: 'C: $\backslash$ Program Files $\backslash$ MINITAB 14

Student|Studnt14\AFOLABI.MPJ'

\section{Descriptive Statistics: PRI2}

Variable Mean StDev

PRI2 $56.3 \quad 89.4$

\section{One-Sample T}

Test of $\mathrm{mu}=95$ vs not $=95$

N Mean StDev SE Mean $95 \%$ CI $\quad$ T $\quad$ P

$\begin{array}{lllllll}225 & 56.3000 & 89.4000 & 5.9600 & (44.5552,68.0448) & -6.49 & 0.000\end{array}$

\section{Descriptive Statistics: PRI8, PUB8}

Variable Mean StDev

$\begin{array}{lll}\text { PRI8 } & 112.5 & 123.7\end{array}$

PUB8 $\quad 62.5 \quad 53.0$

\section{Two-Sample T-Test and CI}

Sample N Mean StDev SE Mean

$\begin{array}{lllll}1 & 225 & 113 & 124 & 8.2\end{array}$

$\begin{array}{lllll}2 & 125 & 62.5 & 53.0 & 4.7\end{array}$

Difference $=\mathrm{mu}(1)-\mathrm{mu}(2)$

Estimate for difference: 50.0000

95\% CI for difference: $(27.1456,72.8544)$

$\mathrm{T}$-Test of difference $=0($ vs not $=): \mathrm{T}$-Value $=4.30 \mathrm{P}$-Value $=0.000 \mathrm{DF}=348$

Both use Pooled StDev $=104.1646$

\section{Descriptive Statistics: PUB9}

Variable Mean StDev

PUB9 $\quad 33.8 \quad 32.0$

\section{One-Sample T}

Test of $\mathrm{mu}=95 \mathrm{vs}$ not $=95$

N Mean StDev SE Mean 95\% CI $\quad$ T $\quad$ P

$12533.800032 .00002 .8622(28.1350,39.4650)-21.380 .000$

\section{Descriptive Statistics: PUB11, PRI11}


$\begin{array}{lrc}\text { Variable } & \text { Mean } & \text { StDev } \\ \text { PUB11 } & 25.0 & 50.3 \\ \text { PRI11 } & 225.00 & *\end{array}$

Two-Sample T-Test and CI

Sample N Mean StDev SE Mean

$\begin{array}{lllll}1 & 225 & 225.00 & 1.00 & 0.067\end{array}$

$\begin{array}{lllll}2 & 125 & 25.0 & 50.3 & 4.5\end{array}$

Difference $=\mathrm{mu}(1)-\mathrm{mu}(2)$

Estimate for difference: 200.000

95\% CI for difference: $(193.410,206.590)$

$\mathrm{T}$-Test of difference $=0($ vs not $=): \mathrm{T}-$ Value $=59.69 \mathrm{P}-$ Value $=0.000 \mathrm{DF}=348$

Both use Pooled StDev $=30.0361$

Descriptive Statistics: PRI15, PUB15

Variable Mean StDev

PRI15 $75.0 \quad 108.5$

PUB15 $62.5 \quad 53.0$

Two-Sample T-Test and CI

Sample N Mean StDev SE Mean

$\begin{array}{lllll}1 & 225 & 75 & 109 & 7.2\end{array}$

$2 \quad 125 \quad 62.0 \quad 53.0 \quad 4.7$

Difference $=\mathrm{mu}(1)-\mathrm{mu}(2)$

Estimate for difference: 13.0000

95\% CI for difference: $(-7.3214,33.3214)$

$\mathrm{T}$-Test of difference $=0($ vs not $=): \mathrm{T}-$ Value $=1.26 \mathrm{P}$-Value $=0.209 \mathrm{DF}=348$

Both use Pooled StDev $=92.6199$

\section{0/23/2013 1:28:01 AM}

Worksheet size: 10000 cells.

Welcome to Minitab, press F1 for help.

Retrieving project from file: 'C: $\backslash$ Program Files $\backslash$ MINITAB 14

Student Studnt14\AFOLABI.MPJ

Descriptive Statistics: PRI16, PUB16

Variable Mean StDev

PRI16 5.0000 *

PUB16 $5.0000 *$

\section{Two-Sample T-Test and CI}

Sample N Mean StDev SE Mean

$\begin{array}{lllll}1 & 225 & 5.00 & 1.00 & 0.067\end{array}$

$\begin{array}{lllll}2 & 125 & 5.00 & 1.00 & 0.089\end{array}$

Difference $=\mathrm{mu}(1)-\mathrm{mu}(2)$

Estimate for difference: 0.000000

95\% CI for difference: $(-0.219406,0.219406)$

$\mathrm{T}$-Test of difference $=0($ vs not $=): \mathrm{T}$-Value $=0.00 \mathrm{P}$-Value $=1.000 \mathrm{DF}=348$

Both use Pooled StDev $=1.0000$ 